\title{
Nitric oxide suppresses EPO-induced monocyte chemoattractant protein-1 in endothelial cells: implications for atherogenesis in chronic renal disease
}

\author{
Anjali Desai, Ying Zhao, Heather A Lankford and Jeffrey S Warren \\ Department of Pathology, University of Michigan Medical School, Ann Arbor, MI, USA
}

\begin{abstract}
Patients with advanced chronic renal disease (CRD) suffer from excessive morbidity and mortality due to complications of accelerated atherosclerosis. Approximately $90 \%$ of dialysis-dependent end stage renal disease patients suffer from anemia. Recombinant human erythropoietin (EPO) in combination with iron has become widely used to treat anemic CRD patients. While treatment with EPO results in improved quality of life it may also contribute to the development of atherosclerosis. Recent studies suggest that a reduction in nitric oxide (NO) availability may be linked to EPO-induced vascular dysfunction. Furthermore, CRD per se is thought to result in a state of NO deficiency. The present study suggests that EPO may exert proatherogenic activity by augmenting the cytokine-induced expression of monocyte-chemoattractant protein-1 (MCP-1) in human umbilical vein endothelial cells (HUVECs) and by stimulating the proliferation of HUVECs and human vascular smooth muscle cells (HVSMCs). Augmentation of MCP-1 expression appears to be linked to EPO-induced downregulation of endothelial NO synthase (ecNOS). NO released from a series of synthetic donor compounds suppressed the EPO-mediated augmentation of cytokine-induced MCP-1 expression. In vitro studies revealed that EPO reduces ecNOS expression at both the protein and mRNA levels and that EPO also mediates a reduction in ecNOS enzymatic activity. These observations suggest potential mechanisms through which EPO may contribute to the development of accelerated atherosclerosis, particularly in the setting of CRD where NO availability may already be compromised.
\end{abstract}

Laboratory Investigation (2006) 86, 369-379. doi:10.1038/labinvest.3700396; published online 13 February 2006

Keywords: chronic renal disease; endothelial cells; erythropoietin; monocyte-chemoattractant protein-1; nitric oxide

Cardiovascular complications resulting from accelerated atherosclerosis are the principal cause of morbidity and mortality in patients with advanced CRD. ${ }^{1}$ The relative risk of death from myocardial infarction has been estimated as between five to 20 times higher in CRD patients than in the age- and sex-matched general population. ${ }^{2,3}$ Chronic administration of recombinant human erythropoietin (EPO), which is widely used to treat the anemia that accompanies CRD and other nonrenal forms of anemia, can result in hypertension and resistance to the vasodilatory action of NO., ${ }^{4,5}$ EPO also exerts a proliferative effect on vascular wall cells. ${ }^{6}$ These

Correspondence: Dr JS Warren, MD, Department of Pathology, University of Michigan Medical School, Box 0602, 1301 Catherine Street, Ann Arbor, MI 48109-0602, USA.

E-mail: warren@med.umich.edu

Received 21 December 2005; accepted 23 December 2005 published online 13 February 2006 actions could potentially contribute to the development of atherosclerotic vascular disease. ${ }^{7}$ While little is known about potential mechanisms, a reduction in NO availability has been linked to EPO-induced vascular dysfunction. ${ }^{8}$

Monocyte-chemoattractant protein-1 (MCP-1), a member of the $\mathrm{C}-\mathrm{C}$ or beta subfamily of chemokines, is pivotal to the recruitment, adhesion, and transendothelial migration of monocytes during atherogenesis. $^{9,10}$ Endothelial NO, on the other hand, is a potent endogenous vasodilator and principal mediator of the antiatherogenic properties of intact endothelium. ${ }^{11}$ Nitric oxide (NO) interferes with monocyte adhesion to the endothelium as well as with platelet-vessel wall interactions. ${ }^{12,13}$ NO decreases endothelial permeability and reduces vascular tone which in turn decrease the flux of lipoproteins into the vessel wall. ${ }^{14,15}$ Exogenous NO as well as NO locally produced by inducible NO synthase (iNOS) in vascular smooth muscle cells 
inhibits oxidation of low-density lipoproteins. ${ }^{16}$ Finally, NO inhibits vascular smooth muscle cell proliferation and migration both in vitro and in vivo. ${ }^{17,18}$

The results of several in vitro and in vivo studies aimed at unraveling a possible link between NO- and EPO-induced vascular dysfunction are in conflict. Del Castillo et $a l^{19}$ observed a significant increase in the urinary excretion of NO metabolites (nitrite and nitrate) in rats treated with EPO for 3 weeks. Similar results were reported by Tsukahara et $a l^{20}$ and Kanagy et $a l^{21}$ who treated rats with EPO over a 2-week period. Wu et $a l^{22}$ observed that EPO stimulates NO release from resting human umbilical vein endothelial cells (HUVECs) in a time and concentration-dependent manner. In contrast, Wang and Vaziri $^{8}$ reported that EPO downregulates basal and acetycholine-induced NO production, depresses endothelial NO synthase (ecNOS) expression and stimulates proliferation of HUVECs. Studies of EPO-induced hypertension in rats with chronic renal failure (CRF) suggest that EPO may induce resistance to the vasodilatory response of arteries to endogenous NO. ${ }^{23}$

In the present study, we observed that exposure of endothelial cells to EPO results in increased endothelial and smooth muscle cell proliferation and downregulation of ecNOS at both the protein and mRNA levels. Futhermore, EPO pretreatment induced a significant rise in cytokine-induced MCP1 concentrations whereas exposure to NO donors immediately following EPO treatment reversed the EPO-mediated increases in cytokine-induced MCP-1 production. These observations suggest that EPO may exert a proatherogenic effect by enhancing the expression of MCP-1 and by stimulating cell proliferation. Coupled with recent reports suggesting that renal failure per se results in a state of NO deficiency, our observation that EPO downregulates ecNOS expression suggests a possible mechanism through which EPO may exacerbate the accelerated atherosclerosis observed in CRD patients. ${ }^{24}$

\section{Materials and methods}

Recombinant human EPO, human tumor necrosis factor- $\alpha$ (TNF- $\alpha$ ), and interleukin-1 $\beta$ (IL-1 $\beta$ ) were obtained from R\&D Systems (Minneapolis, MN, USA). HUVECs, human vascular smooth muscle cells (HVSMCs), and media (EGM-2 and SMGM-2, respectively) were purchased from Clonetics (Walkersville, MD, USA).

\section{Endothelial and Vascular Smooth Muscle Cell Culture}

HUVEC and smooth muscle cells were grown at $37^{\circ} \mathrm{C}$ in $5 \% \mathrm{CO}_{2}$ on $150 \times 25 \mathrm{~mm}^{2}$ plates as previously described. ${ }^{25}$ For all experiments, cells were used between first and third passage.
Treatment of HUVECs for Enzyme Immunoassay (EIA) Experiments

HUVECs were grown to partial confluence on 96-well flat bottom polystyrene plates (Costar). The cells were exposed to EPO $(5 \mathrm{U} / \mathrm{ml})$ for $24 \mathrm{~h}$. In experiments with NONOates, the medium was changed following this $24 \mathrm{~h}$ incubation period. Ten microliters of a concentrated stock solution of NONOate in $0.01 \mathrm{~N} \mathrm{NaOH}$ ( $2 \mathrm{mM}$ ) was added to $190 \mu \mathrm{l}$ of medium to obtain a final concentration of $100 \mu \mathrm{M}$. Following a $30 \mathrm{~min}$ incubation with the NONOate, the conditioned medium was replaced by fresh medium containing TNF- $\alpha(10 \mathrm{ng} / \mathrm{ml})$ or IL- $1 \beta(10 \mathrm{ng} / \mathrm{ml})$. At the time of cytokine stimulation, all endothelial monolayers were confluent. The conditioned media collected at the end of an $8 \mathrm{~h}$ incubation with either TNF- $\alpha$ or IL- $1 \beta$ were subjected to a MCP-1 EIA. A fraction of the conditioned media was also subjected to cytotoxicity detection (LDH) assays (Roche Applied Science, Indianapolis, IN, USA) to assess cell viability. For all experiments cell viability was greater than $95 \%$.

\section{MCP-1 EIA}

MCP-1 capture plates were prepared by coating sterile 96-well flat bottom ELISA plates (Corning, Corning, NY, USA) with anti-human MCP-1 antibody (R\&D Systems, $100 \mu \mathrm{l} /$ well, $0.8 \mu \mathrm{g} / \mathrm{ml}$ in PBS). The plates were incubated at $4{ }^{\circ} \mathrm{C}$ overnight, washed with Wash Buffer (0.05\% Tween-20 in PBS, pH 7.4) and blocked overnight at $4{ }^{\circ} \mathrm{C}$ with blocking buffer $(0.05 \%$ Tween-20, $1 \%$ BSA in PBS, pH 7.4) to reduce nonspecific binding. Capture plates were stored at $4^{\circ} \mathrm{C}$ until use. Hundred microliters aliquots of the conditioned cell media and human recombinant MCP-1 standards (R\&D systems) were loaded onto capture plates and incubated at $4^{\circ} \mathrm{C}$ overnight. Biotinylated anti-human MCP-1 detection antibody (R\&D Systems) was added to each well $(0.1 \mu \mathrm{g} / \mathrm{ml}$, $100 \mu \mathrm{l}$ per well) and plates were incubated at room temperature for $2 \mathrm{~h}$. After three washes, streptavidin horseradish peroxidase was added (Neutralite avidin, Southern Biotechnology Associates, Birmingham, AL, USA; $100 \mu \mathrm{l} /$ well, 1:4000 dilution) and incubated for $30 \mathrm{~min}$ at room temperature. Wells were washed to remove unbound conjugated peroxidase and then incubated with $100 \mu \mathrm{l} /$ well of peroxidase substrate $\left(\mathrm{ABTS}^{\circledR}\right.$, Boehringer Mannheim Biochemica, Germany). After $30 \mathrm{~min}$ to $2 \mathrm{~h}$, optical density (OD) at $405 \mathrm{~nm}$ was measured using an automated microplate reader $\left(\mathrm{EL}_{\mathrm{x}} 808\right.$, Bio-Tek Instruments, Winooski, VT, USA). MCP-1 concentrations were calculated by 4 parameter curve fitting or linear regression analysis of rhMCP-1 standard curves using KC3 software (Bio-Tek Inc.).

\section{Extraction of Nuclear and Cytosolic Protein}

Nuclear extracts were prepared as previously decribed by a modified method of Dignam et al. ${ }^{24}$ 
Briefly, HUVECs $\left(5 \times 10^{6}-5 \times 10^{7}\right.$ cells $)$ were harvested by scraping and centrifuged in PBS for $5 \mathrm{~min}$ at 1200 r.p.m. The pelleted cells were washed twice with $1 \mathrm{ml}$ of ice-cold buffer A ( $10 \mathrm{mM}$ Hepes, $1.5 \mathrm{mM}$ $\mathrm{MgCl}_{2}, 10 \mathrm{mM} \mathrm{KCl}, 0.5 \mathrm{mM}$ dithiothreitol, $0.5 \mathrm{mM}$ PMSF). The pellet was resuspended in $60 \mu \mathrm{l}$ buffer $\mathrm{A}+0.1 \%$ Nonidet $P-40$ and incubated on ice for $5 \mathrm{~min}$. Following centrifugation, the supernatants were diluted in $60 \mu \mathrm{l}$ buffer D (20 mM Hepes, $50 \mathrm{mM}$ $\mathrm{KCl}, 20 \%$ glycerol, $0.5 \mathrm{mM}$ dithiothreitol, $0.5 \mathrm{mM}$ PMSF), frozen at $-80^{\circ} \mathrm{C}$, and subsequently utilized for Western blots. The pelleted nuclei were suspended in $60 \mu \mathrm{l}$ buffer C $(20 \mathrm{mM}$ Hepes, $0.42 \mathrm{M}$ $\mathrm{NaCl}, 1.5 \mathrm{mM} \mathrm{MgCl}_{2}, 25 \%$ glycerol, $0.5 \mathrm{mM}$ dithiothreitol, 0.5 mM PMSF). After incubating the suspension on ice for $15 \mathrm{~min}$, it was vortexed gently and centrifuged. The resulting supernatant was diluted in buffer D, aliquoted, and stored at $-80^{\circ} \mathrm{C}$. Protein determination was carried out by a Micro BCA assay (Pierce, Rockford, IL, USA) using bovine serum albumin as a standard.

\section{Western Blot Analysis}

Cytoplasmic extracts (corresponding to $5 \mu \mathrm{g}$ total protein) were denatured in Tris-glycine sample buffer (Novex, San Diego, CA, USA) and electrophoresed on $4-20 \%$ Tris-glycine gels using Tris/ Glycine/SDS running buffer (Bio-Rad, Minneapolis, MN, USA). Rainbow markers (Amersham) were used as molecular weight standards. The proteins were transferred to a nitrocellulose membrane using a mini-Trans blot for $6 \mathrm{~h}$ at room temperature with $250 \mathrm{~mA}$ of current. Blots were blocked overnight with a solution of $1 \%$ BSA in Tris-buffered saline (TBS) containing $0.1 \%$ Tween-20 (TBS-T). After three washes with TBS-T, the ecNOS antibody (Transduction Laboratories, N30020) was added at a dilution of 1:2500 and the blots were incubated for $1 \mathrm{~h}$. Blots were washed rapidly three times in TBS-T. The blots were incubated for $20 \mathrm{~min}$ in TBS-T containing the detection antibody anti-mouse IgG conjugated with horseradish peroxidase (Santa Cruz Biotechnology, Santa Cruz, CA, USA) at a dilution of 1:5000. Immunoreactive bands were visualized using an enhanced chemiluminescence light detecting kit (Pierce).

\section{Ribonuclease (RNase) Protection Assay (RPA)}

Total RNA was extracted from endothelial cells using Tri Reagent according to manufacturer's instructions. The RNase protection assays were performed usig the RiboQuant Multi-probe kit from Pharmingen (San Diego, CA, USA) and carried out as instructed by the manufacturer. Briefly, chemokine probes were radiolabeled with $\left[\gamma_{-}{ }^{32} \mathrm{P}\right]$ UTP (Amersham) and hybridized with the extracted total RNA at $56^{\circ} \mathrm{C}$ overnight. RNase digestion was carried out at $30^{\circ} \mathrm{C}$ for $45 \mathrm{~min}$ to digest unhybridized single- stranded and excess probe and terminated by the addition of proteinase K. After phenol/chloroform extraction and ammonium acetate/ethanol precipitation, the hybridized RNA probes were denatured at $90^{\circ} \mathrm{C}$ for $3 \mathrm{~min}$ and loaded onto a denaturing gel $(5 \%$ acrylamide, $7 \mathrm{M}$ urea) which was run in $0.5 \times \mathrm{TBE}$ at $55 \mathrm{~W}$ constant power for $1.5 \mathrm{~h}$. Gels were vacuum-dried at $50^{\circ} \mathrm{C}$ for $90 \mathrm{~min}$, placed on Kodak X-OMAT film in an autoradiography cassette with an intensifying screen and developed at $-70^{\circ} \mathrm{C}$.

\section{mRNA Quantification}

MCP-1 mRNA levels were quantified using a commercially available colorimetric micoplate assay kit (Quantikine mRNA; R\&D Systems, Minneapolis, MN, USA) according to the manufacturere's instructions. The lower detection limit is 3.9 amol MCP-1 $\mathrm{mRNA} / \mathrm{mL}$.

\section{Electrophoretic Mobility Shift Assay}

Electrophoretic mobility shift assays (EMSAs) were carried out using a gel shift assay system kit (Promega, Madison, WI, USA). Double-stranded $\mathrm{NF}-\kappa \mathrm{B}$ consensus oligonucleotide probe $\left(5^{\prime}\right.$-AGT TGA GGG GAC TTT CCC AGC C-3') or AP-1 consensus probe (5'-CGC TTG ATG AGT CAG CCG GAA-3 $)$ was end-labeled with $\left[\gamma^{-32} \mathrm{P}\right]$ ATP $(3000 \mathrm{Ci} / \mathrm{mmol}$ at $10 \mathrm{mCi} / \mathrm{ml}$, Amersham Life Science, Arlington Heights, IL, USA) and polynucleotide kinase (Promega). Following end-labeling, oligonucleotide probe and nuclear protein $(5 \mu \mathrm{g})$ were incubated for $30 \mathrm{~min}$ at room temperature in binding buffer (Promega). Samples were run on a nondenaturing $4 \%$ polyacrylamide gel in $0.25 \times \mathrm{TBE}$ buffer at $100 \mathrm{~V} / 10 \mathrm{~mA}$ for $3 \mathrm{~h}$. Gels were vacuum dried at $50^{\circ} \mathrm{C}$ for $90 \mathrm{~min}$ and visualized by Kodak $\mathrm{X}$-OMAT film exposure to the gel at $-70^{\circ} \mathrm{C}$ overnight.

\section{Nitric Oxide Synthase Assay}

NOS activity was measured using a NOS detect assay kit (Stratagene, La Jolla, CA, USA) according to manufacturer's directions. Endothelial monolayers were incubated for $24 \mathrm{~h}$ either in medium alone or with the addition of EPO $(5 \mathrm{U} / \mathrm{ml})$. The cells were washed with PBS, harvested, and homogenized. Protein determination was carried out by a Micro BCA assay (Pierce, Rockford, IL, USA) using bovine serum albumin as a standard.

\section{Bromodeoxyuridine (BrdU) Assay}

BrdU Assay was performed using a Cell Proliferation ELISA kit from Roche Diagnostics $\mathrm{GmbH}$ (Mannheim, Germany). HUVECs and smooth muscle cells were grown to partial confluence on 96-well plates. The cells were incubated for $24 \mathrm{~h}$ in 
the presence of medium with or without varying concentrations of EPO or doxorubicin (DOX). The medium was removed and the cells were treated with fresh medium containing $10 \mu \mathrm{l}$ of BrdUlabeling reagent. After processing the microtiter plate as instructed by the manufacturer, absorbance at $340 \mathrm{~nm}$ with a reference wavelength of $490 \mathrm{~nm}$ $\left(\mathrm{A}_{340-490}\right)$ was measured using an automated microplate reader $\left(\mathrm{EL}_{\mathrm{x}} 808\right.$, Bio-Tek Instruments, Winooski, VT, USA).

\section{Densitometric Scanning}

Autoradiographs from RPAs were scanned using Polaroid PhotoMAX Pro and integrated densities were determined using Scion Image for windows (Scion Corporation, Frederick, MD, USA). To adjust for differences in sample loading between wells, ecNOS mRNA levels were expressed as ratios of integrated densities for ecNOS to GAPDH products.

\section{Statistical Analysis}

Statistical analysis was performed using Statistics for Windows, version 2.0. All values are expressed as means \pm s.e. Data were analyzed using Friedman two-way analysis of variance (ANOVA) with Bonferroni comparison of means. Probability $(P)$ values of $<0.05$ were considered significant.

\section{Results}

\section{Recombinant Human EPO Augments Cytokine-Induced MCP-1 Expression in HUVECS}

As previously reported, exposure of confluent HUVEC monolayers to either TNF- $\alpha$ or IL- $1 \beta$ alone results in marked increases in MCP-1 production when compared to unstimulated HUVECs. ${ }^{25}$ Pretreatment with EPO significantly increased MCP-1 secretion by cytokine-stimulated endothelial cells. OD readings at $405 \mathrm{~nm}$ in MCP-1 ELISAs (using ABTS as a substrate) were 2.6-fold elevated in conditioned media from HUVECs that were pretreated with $1 \mathrm{U} / \mathrm{ml}$ of EPO prior to cytokine stimulation compared to cells pretreated with medium (control). With $5 \mathrm{U} / \mathrm{ml}$ EPO, OD readings were 5.1-fold elevated over control and with $25 \mathrm{U} / \mathrm{ml} \mathrm{EPO,}$ 4.3-fold elevated over control. Cytokine-induced MCP-1 concentrations were not elevated when HUVECs were pretreated with EPO between 3 and $13 \mathrm{~h}$. Increases in IL-1 induced MCP-1 concentrations were only observed at two later time points that we examined at 24 and $25 \mathrm{~h}$. When HUVECs were pretreated with EPO $(5 \mathrm{U} / \mathrm{ml})$ for $24 \mathrm{~h}, \mathrm{TNF}-\alpha$ and IL-1 $\beta$ stimulation resulted in 181 and $151 \%$, respectively, increases in MCP-1 secretion (Figure 1). Heatinactivated EPO $(5 \mathrm{U} / \mathrm{ml})$ had no effect on cytokineinduced MCP-1 expression (data not shown).

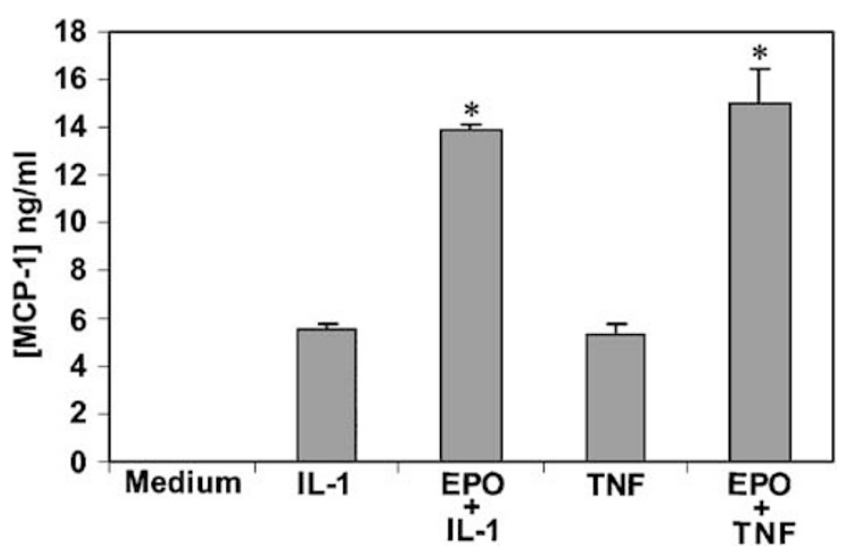

Figure 1 Augmentation of cytokine-induced MCP-1 production by EPO. HUVECs were pretreated for $24 \mathrm{~h}$ with either medium or EPO $(5 \mathrm{U} / \mathrm{ml})$, followed by a $8 \mathrm{~h}$ incubation in the presence of $\mathrm{IL}-1 \beta(10 \mathrm{ng} / \mathrm{ml})$ or TNF- $\alpha(10 \mathrm{ng} / \mathrm{ml})$. These data represent mean \pm s.e. from three independent experiments, each performed in triplicate. ${ }^{*}$ Statistically significant difference $(P<0.05)$ from positive control (ie IL- $1 \beta$ or TNF- $\alpha$ alone).

\section{EPO does not Augment MCP-1 Concentrations by} Increasing Translocation of NF- $\kappa$ B in HUVECs

Cytokine-induced MCP-1 gene expression in endothelial cells depends on the cooperative interaction of the redox-sensitive transcription factors NF- $\kappa \mathrm{B}$ and AP-1. ${ }^{26,27}$ Nuclear extracts derived from HUVECs exposed to $5 \mathrm{U} / \mathrm{ml}$ of EPO or medium, respectively, for $24 \mathrm{~h}$ followed by cytokine exposure for 45 min were subjected to EMSAs with NF- $\kappa$ B and AP-1 consensus oligonucleotides. As expected, cytokine stimulation of HUVECs resulted in a marked increase in the cytosolic-to-nuclear translocation of NF- $\kappa \mathrm{B}$ (Figure 2). EPO treatment prior to cytokine activation, however, did not affect NF- $\kappa \mathrm{B}$ activation and translocation. While EPO treatment augmented IL- $1 \beta$-induced activation of AP- 1 , it had no effect on TNF- $\alpha$-induced AP-1 activation (Figure 3).

\section{EPO does not Augment Cytokine-Induced MCP-1 mRNA Concentrations in HUVECs}

Both, RNase protection and colorimetric microplate assays were used to determine whether increased levels of MCP-1 mRNA were present in EPO pretreated endothelial cells (Figure 4). In the RNase protection assays (Figure 4a) no MCP-1 mRNA was detected in HUVECs that had been exposed to medium or EPO alone, respectively, for $24 \mathrm{~h}$. As expected, exposure of HUVECs to either TNF- $\alpha$ or IL- $1 \beta$ for $4 \mathrm{~h}$ resulted in induction of MCP-1 mRNA. When HUVECs were treated with EPO for $24 \mathrm{~h}$ prior to cytokine stimulation no increases in MCP-1 mRNA were observed when compared to cells that were pretreated with medium for $24 \mathrm{~h}$ prior to IL- $1 \beta$ or TNF- $\alpha$ stimulation. Results from mRNA quantitation assays depicted in Figure $4 \mathrm{~b}$ concur 


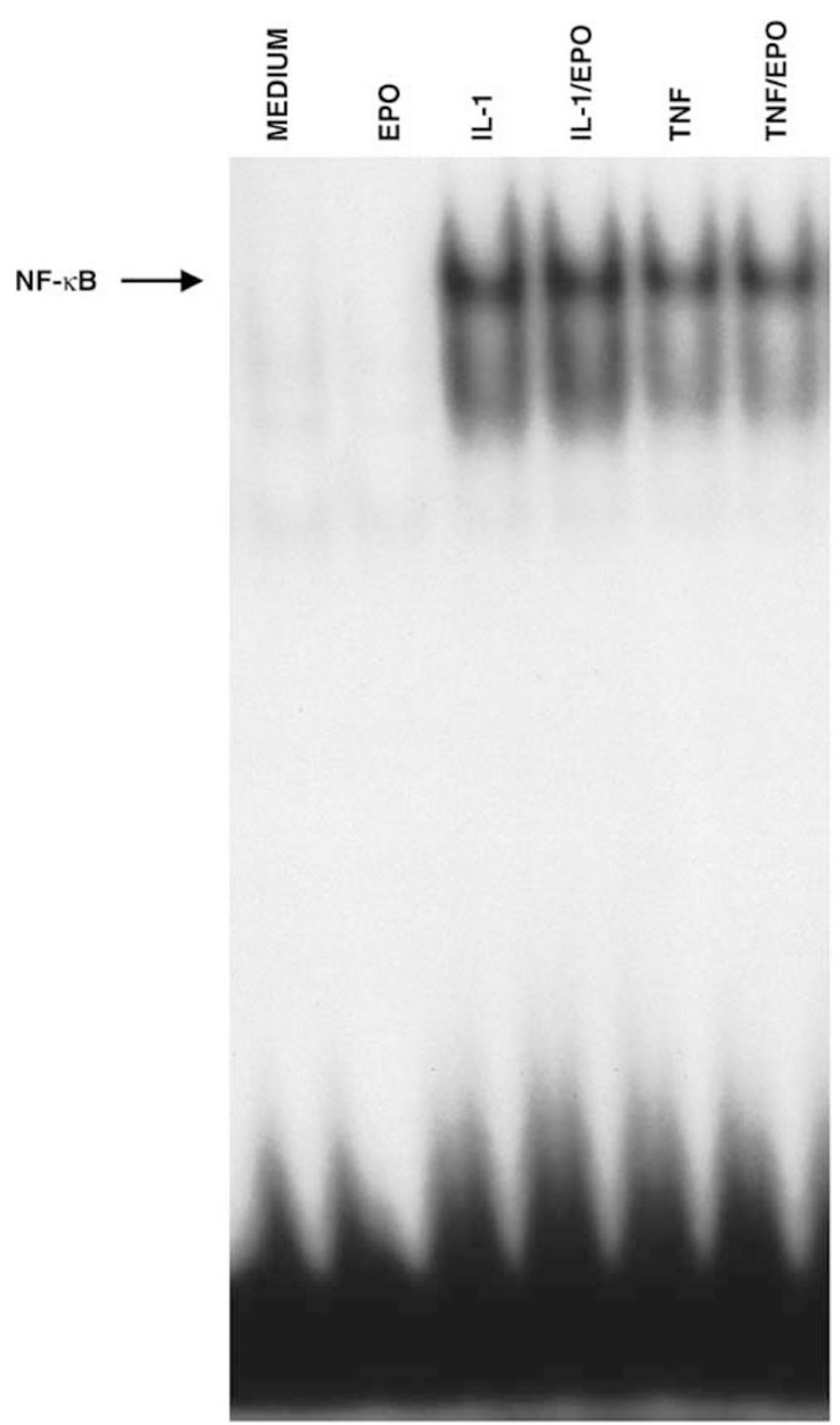

Figure 2 Effect of EPO on cytokine-induced NF- $\kappa$ B translocation. HUVECs were subjected to a $24 \mathrm{~h}$ pretreatment with either medium or EPO $(5 \mathrm{U} / \mathrm{ml})$, followed by a $45 \mathrm{~min}$ incubation in the presence of IL-1 $\beta(10 \mathrm{ng} / \mathrm{ml})$ or TNF- $\alpha(10 \mathrm{ng} / \mathrm{ml})$, respectively. Nuclear extracts were incubated in the presence of a NF- $\kappa$ B consensus oligonucleotide probe for $30 \mathrm{~min}$ at room temperature and samples were run on a nondenaturing $4 \%$ polyacrylamide gel. Addition of unlabeled (cold) NF- $\kappa \mathrm{B}$ consensus oligonucleotide to the extract derived from TNF- $\alpha$-stimulated HUVECs abrogated the gel shift (data not shown). These data are representative of three independent experiments.

with those obtained from the RNase protections assays presented in Figure 4a. Low concentrations of MCP-1 mRNA (between $292 \pm 23$ and $440 \pm 84 \mathrm{amol} /$ $\mathrm{ml}$ ) were measured in ECs treated with medium or EPO, respectively, for $24 \mathrm{~h}$. Following cytokine stimulation, MCP-1 mRNA concentrations were between eight and nine times higher than in media-treated cells. When ECs were treated with EPO for $24 \mathrm{~h}$ prior to cytokine stimulation, no changes in MCP-1 mRNA were measured when compared to cells that were pretreated with medium for $24 \mathrm{~h}$ prior to IL- $1 \beta$ or TNF- $\alpha$ stimulation.

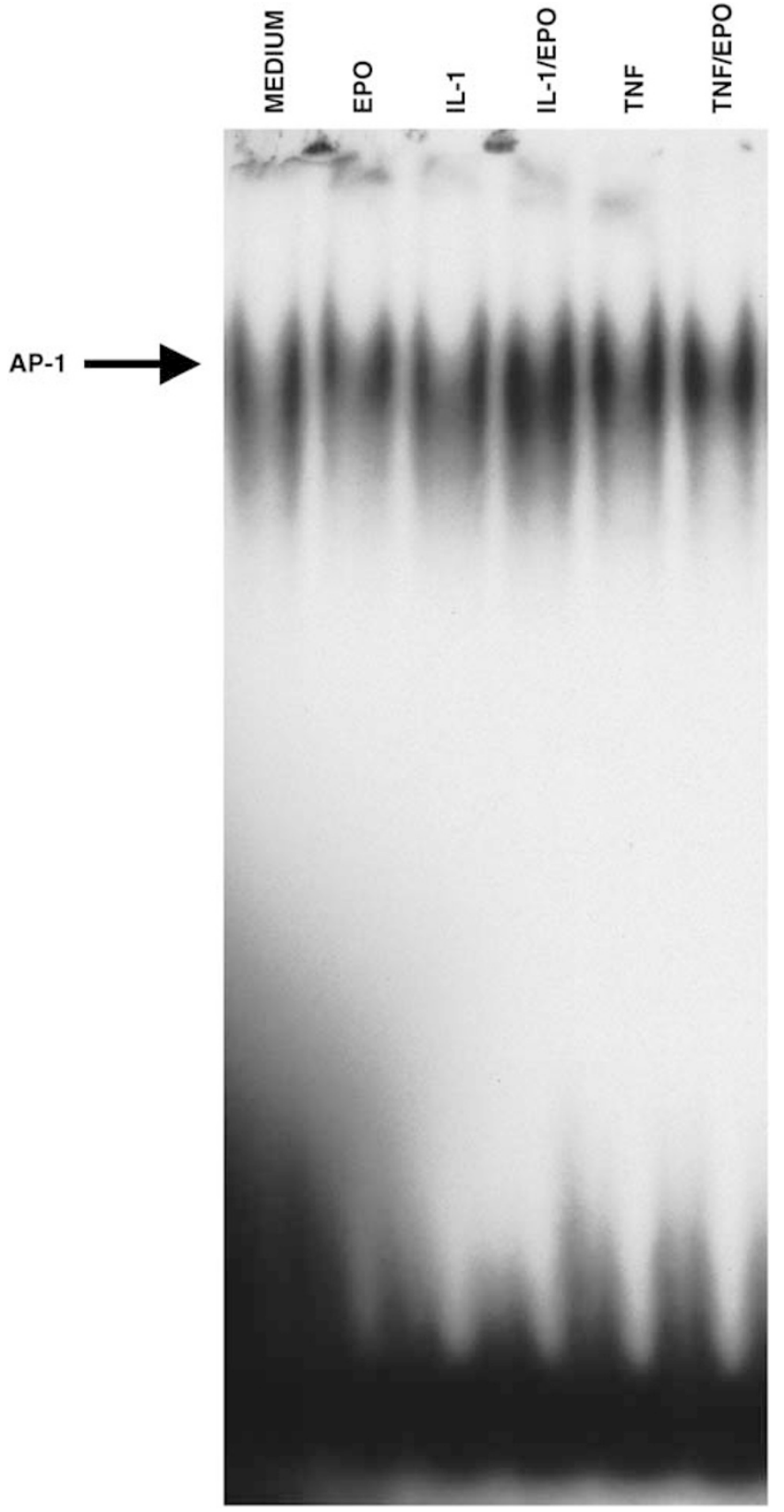

Figure 3 Effect of EPO on cytokine-induced AP-1 activation. HUVECs were subjected to a $24 \mathrm{~h}$ pretreatment with either medium or EPO $(5 \mathrm{U} / \mathrm{ml})$, followed by a $45 \mathrm{~min}$ incubation in presence of IL- $1 \beta(10 \mathrm{ng} / \mathrm{ml})$ or TNF- $\alpha(10 \mathrm{ng} / \mathrm{ml})$, respectively. Nuclear extracts were incubated in presence of an AP-1 consensus oligonucleotide probe for $30 \mathrm{~min}$ at room temperature and samples were run on a nondenaturing $4 \%$ polyacrylamide gel. Addition of unlabeled (cold) AP-1 consensus oligonucleotide to the extract derived from TNF- $\alpha$-stimulated HUVECs abrogated the gel shift (data not shown). These data are representative of three independent experiments.

\section{NO Suppresses EPO-Mediated Augmentation of Cytokine-Induced MCP-1 Expression in HUVECs}

It is currently believed that tonic production of NO by vascular endothelial cells plays an important role in the regulation of vascular tone and in retarding atherogenesis. ${ }^{11}$ Dose-response and 

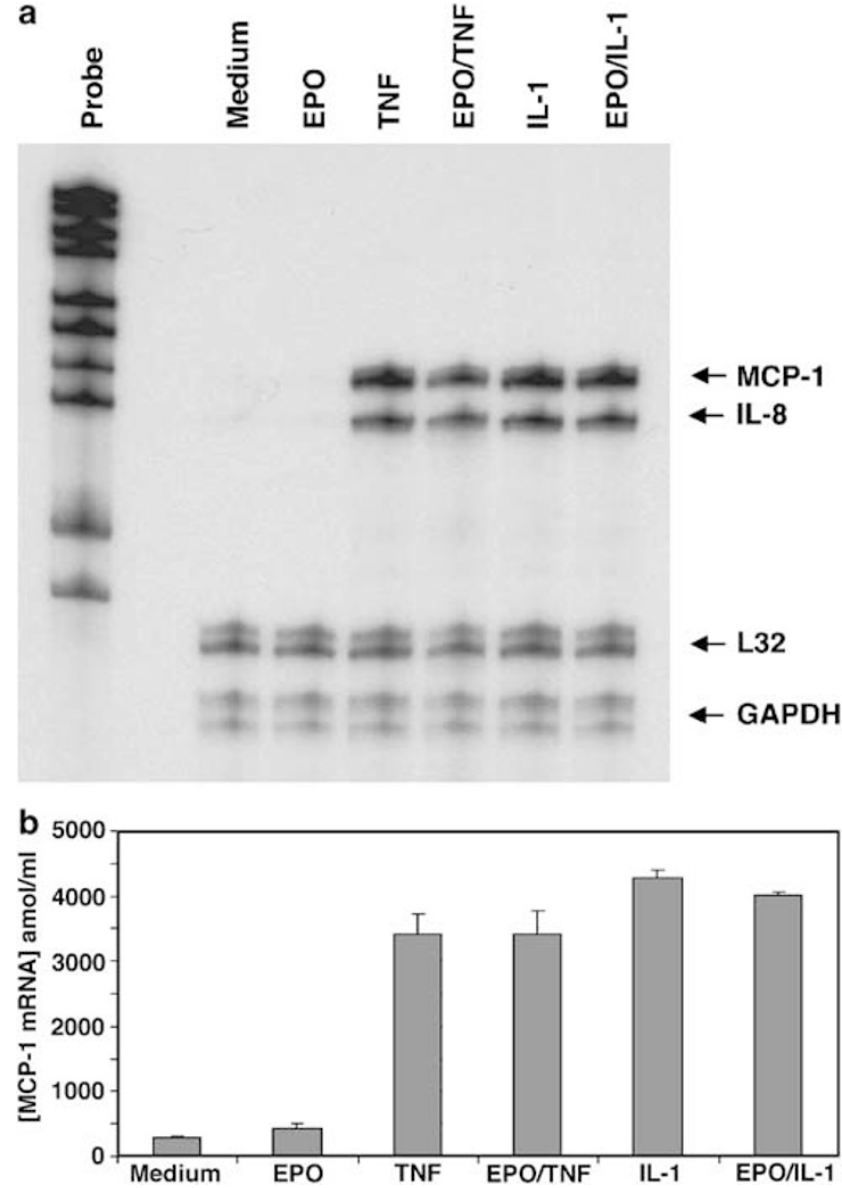

Figure 4 MCP-1 mRNAs in cytokine-activated HUVECs detected by (a) ribonuclease protection assays and (b) colorimetric mRNA quantitation assays. Cells were exposed to $5 \mathrm{U} / \mathrm{ml} \mathrm{EPO} \mathrm{or} \mathrm{medium}$ for $24 \mathrm{~h}$ followed by cytokine (TNF- $\alpha$ or IL- $1 \beta$ at $10 \mathrm{ng} / \mathrm{ml}$, respectively) or medium, respectively, for $4 \mathrm{~h}$. In the experiments depicted in (a), specific transcripts for MCP-1 and the 'housekeeping' genes, L32 and GAPDH as controls were detected by ribonuclease protection assays. In the experiments shown in (b), total mRNA was hybridized with MCP-1 gene-specific biotinlabeled capture oligonucleotide probes and digoxigenin-labeled detection probes. Both data sets are representative of two independent experiments. In the mRNA quantitation assay each sample was analyzed in duplicate.

time course experiments employed chemical NO donors (NONOates) with varying half-lives (PAPA NONOate $\left(t_{1 / 2}=15 \mathrm{~min}\right.$ at $\left.\mathrm{pH} 7.4,37^{\circ} \mathrm{C}\right)$, diethylamine NONOate $\left(t_{1 / 2}=2 \mathrm{~min}\right.$ at $\left.\mathrm{pH} 7.4,37^{\circ} \mathrm{C}\right)$, and spermine NONOate $\left(t_{1 / 2}=39 \mathrm{~min}\right.$ at $\left.\left.\mathrm{pH} 7.4,37^{\circ} \mathrm{C}\right)\right)$. Compared to cells that were treated with TNF- $\alpha$ or IL-1 $\beta$ alone, EPO pretreatment (followed by either TNF- $\alpha$ or IL-1 $\beta$ ) induced significant increases in MCP-1 concentrations (Figure 5). When EPO-pretreated cells were incubated with PAPA NONOate for $30 \mathrm{~min}$ prior to TNF- $\alpha$ or IL- $1 \beta$ stimulation, a significant decrease in MCP-1 concentration was observed when compared to cells that were treated with EPO and cytokine (IL- $1 \beta$ or TNF- $\alpha$, respectively). Similar results were observed when the NO donors diethylamine and spermine NONOate (data not shown) were employed.
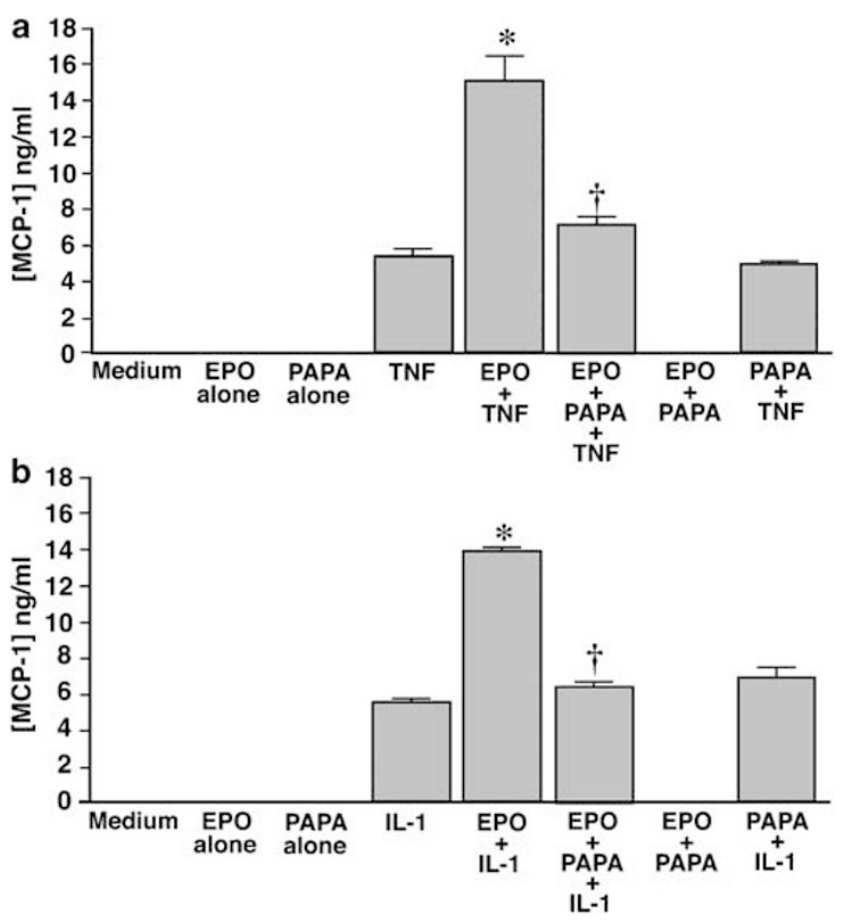

Figure 5 (a) Suppression of the EPO-mediated augmentation of TNF- $\alpha$-induced MCP-1 expression by PAPA NONOate. HUVECs were pretreated for $24 \mathrm{~h}$ with either medium or EPO $(5 \mathrm{U} / \mathrm{ml})$, followed by a $30 \mathrm{~min}$ incubation with medium or PAPA NONOate $(100 \mu \mathrm{M})$. The cells were subsequently exposed to either medium or TNF- $\alpha(10 \mathrm{ng} / \mathrm{ml})$ for $8 \mathrm{~h}$. These data represent mean \pm s.e. from three independent experiments, each performed in triplicate. ${ }^{*}$ Significant difference from positive control (TNF- $\alpha$ alone). "Statistically significant difference $(P<0.05)$ from HUVECs treated with a combination of EPO and TNF- $\alpha$. (b) Suppression of the EPO-mediated augmentation of IL-1 $\beta$-induced MCP-1 expression by PAPA NONOate. HUVECs were pretreated for $24 \mathrm{~h}$ with either medium or EPO $(5 \mathrm{U} / \mathrm{ml})$, followed by a $30 \mathrm{~min}$ incubation with medium or PAPA NONOate $(100 \mu \mathrm{M})$. The cells were subsequently exposed to either medium or IL- $1 \beta(10 \mathrm{ng} / \mathrm{ml})$ for $8 \mathrm{~h}$. These data represent mean \pm s.e. from three independent experiments, each performed in triplicate. ${ }^{*}$ Significant difference from positive control (IL-1 $\beta$ alone). "Statistically significant difference $(P<0.05)$ from HUVECs treated with a combination of EPO and IL-1 $\beta$.

\section{Recombinant Human EPO Downregulates the Expression of ecNOS in HUVECs}

HUVECs maintained in medium for $24 \mathrm{~h}$ expressed high concentrations of ecNOS as measured by Western blot (Figure 6, lane 2). No differences in ecNOS expression were seen in HUVECs grown in the presence of 1 or $25 \mathrm{U} / \mathrm{ml}$, respectively, of EPO for $24 \mathrm{~h}$. Marked suppression of ecNOS expression occurred after a $24 \mathrm{~h}$ incubation in the presence of $5 \mathrm{U} / \mathrm{ml}$ EPO (Figure 6, lane 4).

\section{EPO Treatment Reduces ecNOS mRNA Concentrations in HUVECs}

RNase protection experiments revealed that a $24 \mathrm{~h}$ treatment of HUVECs with EPO $(5 \mathrm{U} / \mathrm{ml})$ resulted in 
a $64 \%$ reduction in ecNOS mRNA when compared to HUVECs incubated in medium alone (Figure 7, see integrated density ratios).

\begin{tabular}{lc}
\multicolumn{2}{c}{$\begin{array}{c}\text { Integrated densities of } \\
\text { ecNOS protein band } \\
\% \text { of control (Medium) }\end{array}$} \\
\hline Medium & 100 \\
EPO $(1 \mathrm{U} / \mathrm{ml})$ & $106.7 \pm 5.0$ \\
EPO $(5 \mathrm{U} / \mathrm{ml})$ & $54.3 \pm 12.6$ \\
EPO $(25 \mathrm{U} / \mathrm{ml})$ & $90.9 \pm 4.15$
\end{tabular}

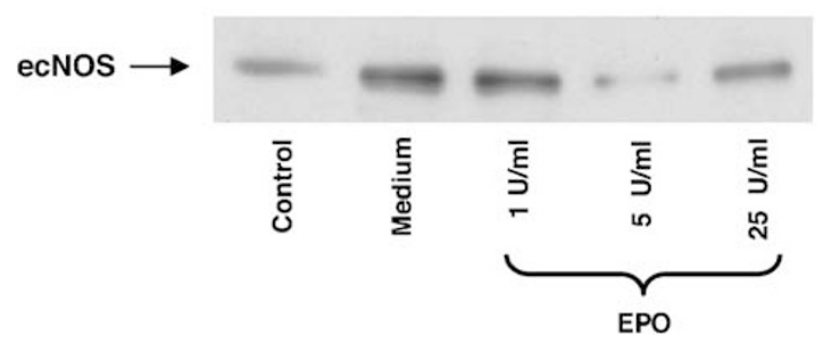

Figure 6 Downregulation of ecNOS protein expression by EPO. HUVECs were treated with the specified concentrations of EPO or medium for $24 \mathrm{~h}$. The protein expression of ecNOS was measured by Western blot. Control (lane 1) represents a human endothelial lysate derived from an aortic endothelial cell line that was provided with the ecNOS antibody. All lanes in the gel were loaded with equal amounts of total protein and integrated densities of the ecNOS protein bands obtained from scannings of autoradiographs from two independent experiments are displayed in the table.

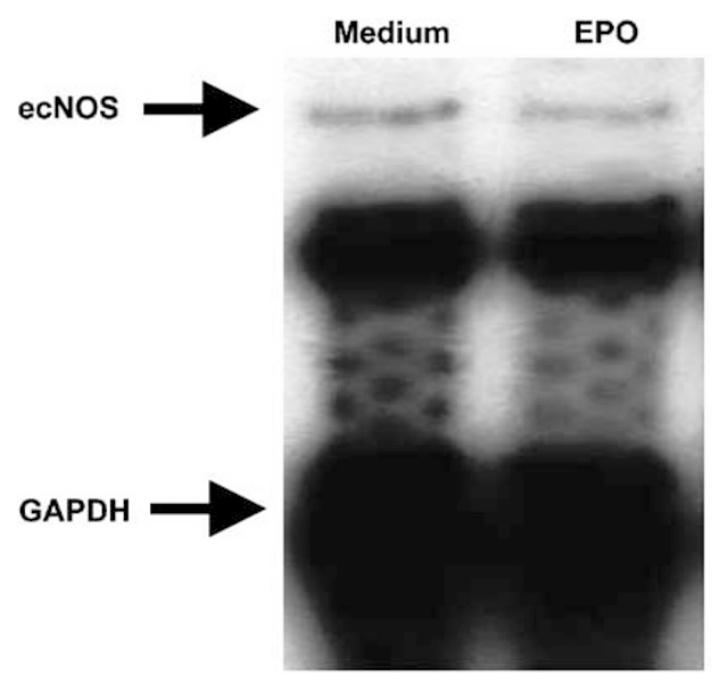

$\underline{\text { Ratio of integrated densities ecNOS/GAPDH }}$

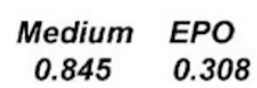

Figure 7 Downregulation of ecNOS mRNA expression by EPO. HUVECs were treated with medium or EPO $(5 \mathrm{U} / \mathrm{ml})$ for $24 \mathrm{~h}$. Total RNA was extracted and utilized in a ribonuclease protection assay. Integrated densities of the ecNOS mRNA bands are displayed below. These data are representative of three independent experiments.

\section{EPO Decreases NOS Activity in HUVECs}

To elucidate whether the decrease in NOS-specific mRNA and protein concentrations also resulted in reduced enzymatic activity, we performed a NOS detect assay. This assay is based on the NOScatalyzed conversion of radiolabeled L-arginine to L-citrulline. In HUVECs incubated in the presence of $5 \mathrm{U} / \mathrm{ml}$ EPO for $24 \mathrm{~h}$, NOS activity was reduced by $28 \%$ when compared to media-treated control cells.

\section{EPO Stimulates Cell Proliferation in HUVECs and HVSMCs}

Atherosclerosis is a fibroproliferative disease of the arterial intima. ${ }^{28}$ The effect of EPO treatment on endothelial cell and smooth muscle cell proliferation was assessed using a BrdU assay. EPO treatment alone (at 1 and $5 \mathrm{U} / \mathrm{ml}$ ) significantly increased HUVEC proliferation (Figure 8a). Nearly identical results were observed in HVSMCs (Figure 8b). Treatment with $1 \mu \mathrm{M}$ DOX inhibited proliferation of both HUVECs and HVSMCs.
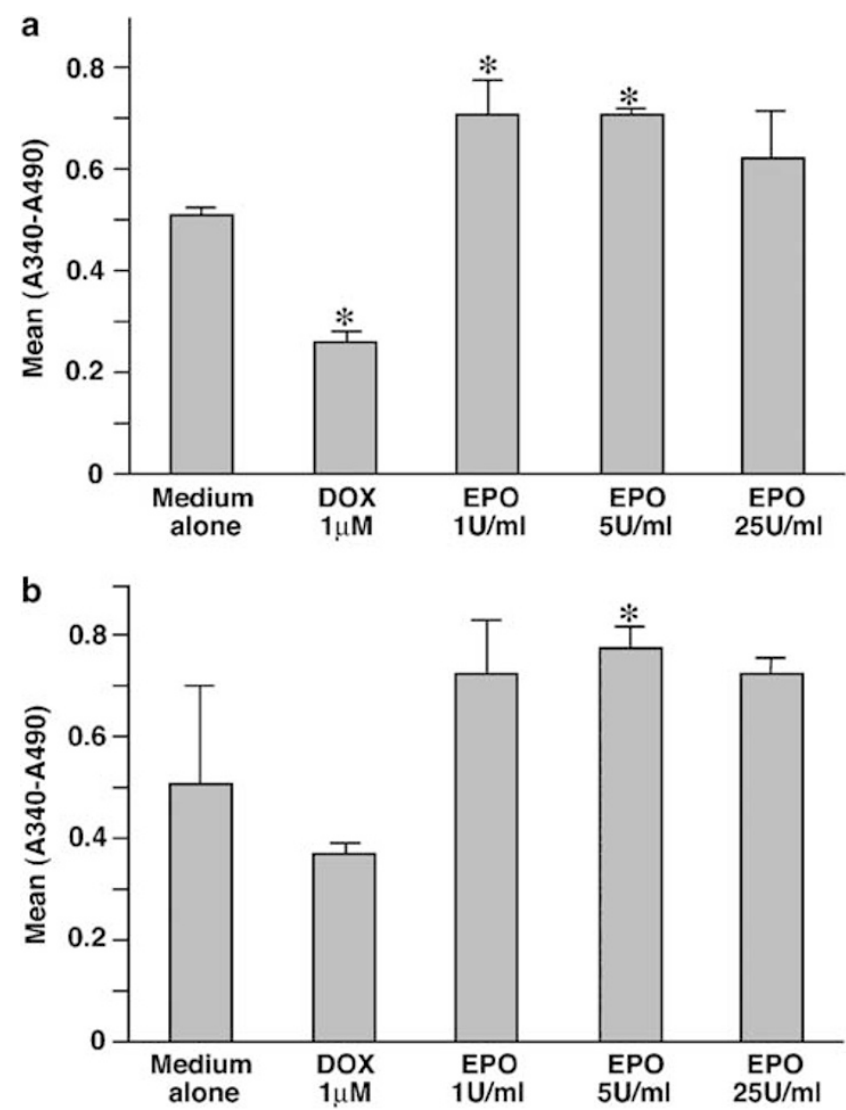

Figure 8 Stimulation of endothelial and smooth muscle cell proliferation by EPO. HUVECs (a) and HVSMCs (b) were exposed to the specified concentrations of EPO or $1 \mu \mathrm{M}$ doxorubicin for $24 \mathrm{~h}$ and then incubated in the presence of BrdU for $20 \mathrm{~h}$. Incorporation of BrdU into proliferating cells was quantitated by immunoassay. These data represent mean \pm s.e. from three independent experiments, each performed in triplicate. *Significant difference from control (medium alone) as determined by Bonferroni comparison of means. 


\section{Discussion}

The advents of both dialysis and renal transplantation in patients with chronic renal disease (CRD) have reduced the mortality rate due to uremia. Accelerated cardiovascular disease has become the leading cause of death in this patient population. EPO, currently the drug with the highest sales worldwide is routinely used to treat the anemia of CRD patients and those with other nonrenal forms of anemia. ${ }^{29}$ While treatment with EPO has severely reduced the transfusion requirements and clearly results in an improved quality of life in CRD patients it may also contribute to vascular dysfunction. ${ }^{4,5}$ Several studies have suggested that EPO may contribute to the development of hypertension and thrombosis. ${ }^{3,30}$ Resistance to the vasodilatory effects of NO has been implicated in these processes. ${ }^{23}$ Research aimed at elucidating a possible link between NO and EPO-induced vascular dysfunction has yielded conflicting results. ${ }^{8,19,20,22,23,31}$

The present study indicates that EPO may exert proatherogenic activity by stimulating endothelial and smooth muscle cell proliferation and by augmenting cytokine-induced expression of MCP-1 in ECs. Exogenous NO suppresses the EPOmediated increases in cytokine-induced MCP-1 expression. EPO downregulates ecNOS expression at both the protein and mRNA level and suppresses NOS activity. These observations suggest that there is an interplay between NO and EPO in the expression of MCP-1 by vascular wall cells and that NO can prevent the EPO-mediated augmentation of cytokine-induced endothelial MCP-1 production. The EPO-mediated upregulation of MCP-1 expression detected by EIA is not accompanied by increased cytosolic-to-nuclear translocation of $N F-\kappa \mathrm{B}$. Whether the EPO-mediated augmentation of IL- $1 \beta$-induced MCP-1 expression is a result of increased AP-1 activation is unclear. However, since RNase protection and mRNA quantitation assays failed to reveal increases in cytokine-induced MCP1 mRNA concentrations following EPO pretreatment, the marked rise in MCP-1 protein concentrations detected by EIA does not appear to occur at the transcriptional level. While our study does not address mechanistic aspects of the EPO-induced upregulation of MCP-1 expression, post-transcriptional regulation of MCP-1 gene expression may present a plausible explanation. In this regard, recent evidence suggests that gene expresson is regulated, at least in part, at a post-transcriptional level by factors inducing the extremely rapid degradation of messenger RNAs. $^{32}$ In fact, Brueckmann et al ${ }^{33}$ recently observed that activated protein C upregulates MCP-1 expression in HUVECs. Similar to our observations, MCP-1 upregulation in their experiments was not accompanied by increased $\mathrm{NF}-\kappa \mathrm{B}$ and $\mathrm{AP}-1$ activation. Using the same type of colorimetric mRNA quantitation assays employed in our studies, the authors concluded that upregulation of MCP-1 occurred most probably by increasing MCP-1 mRNA stability rather than through transcriptional activation via the $\mathrm{NF}-\kappa \mathrm{B}$ or AP-1 pathway.

Several reports indicate that treatment of endothelial and smooth muscle cells with EPO results in an augmentation of intracellular calcium concentrations and in the activation of tyrosine kinasemediated signaling pathways. ${ }^{34,35}$ However, the EPO concentrations used in these studies are significantly higher (up to $250 \mathrm{U} / \mathrm{ml}$ ) than those used in our experiments. In the present study, EPO was used at a concentration of $5 \mathrm{U} / \mathrm{ml}$ in all experiments except the dose-response effect on ecNOS protein expression. Even in this experiment $5 \mathrm{U} / \mathrm{ml}$ was found to be the optimal concentration required to downregulate ecNOS expression (Figure 6). Although we do not have an explanation for this dose-response effect, our observations are supported by reports from other laboratories. Anagnostou et $a l^{36}$ serendipitously noticed the mitogenic effects of EPO on endothelial cells and were the first to report optimal stimulation of cell proliferation by EPO at $5 \mathrm{U} / \mathrm{ml}$ when concentrations up to $20 \mathrm{U} / \mathrm{ml}$ were tested. Subsequently, a number of published studies have documented biological effects of EPO on vascular smooth muscle and endothelial cells. ${ }^{8,34-37}$ In all of these in vitro studies the concentrations of EPO used range from 4 to $250 \mathrm{U} / \mathrm{ml} .^{6,8,31,37}$ While the physiological concentrations of EPO in most healthy animals and humans are in the range of $4-30 \mathrm{mU} / \mathrm{ml}$, up to 100 -fold increases can be seen in severe anemias (thus resulting in plasma concentrations as high as $3 \mathrm{U} / \mathrm{ml}) \cdot{ }^{36,38}$ Furthermore, relatively high EPO plasma concentrations in the order of $1-5 \mathrm{U} / \mathrm{ml}$ may be obtained intermittently in patients immediately after intravenous injection of the hormone. ${ }^{6,39,40}$

Our observation that EPO stimulates proliferation of endothelial and vascular smooth muscle cells is particularly interesting in view of the fact that an increased intima/media thickness of the carotid artery has been observed in hemodialysis patients when compared to age-matched healthy controls but to our knowledge no published study to date has directly addressed the effect of EPO therapy on vessel wall cell proliferation in vivo. ${ }^{41}$

It is currently believed that early atherosclerosis is marked by a reduction in endothelial NO production. ${ }^{11}$ Schmidt and Baylis ${ }^{24}$ reported that patients with CRF are in a NO-deficient state. Reduced vascular NOS activity and ecNOs and iNOS expression were also observed in rats with surgically induced $\mathrm{CRF}^{42}$ In these animals, calcium channel blockade resulted in a significant rise in urinary excretion and plasma concentrations of nitrite and nitrate to supranormal values. This was accompanied by a complete restoration of renal and vascular tissue ecNOS and iNOS proteins. These data suggest that the CRF-associated downregulation of vascular ecNOS and iNOS may be due to dysregulation of 
intracellular calcium. Since EPO has been shown to augment intracellular calcium stores both in vivo and in vitro, EPO-mediated downregulation of NOS expression may result from a dysregulation of calcium homeostasis. ${ }^{43}$ In the context of these findings, our observation that exogenous NO reverses the EPO-mediated augmentation of cytokine-induced MCP-1 expression and that EPO downregulates ecNOS, suggests a possible mechanism through which EPO may contribute to the accelerated atherosclerosis of CRD patients. However, the results from our in vitro studies must be extrapolated to the CRD population with great caution since our observations have not yet been confirmed in vivo and EPO is not only administered to patients with CRD but also to those that suffer from various nonrenal forms of anemia. It is noteworthy that our results are supported by a recent study by Wang and Vaziri ${ }^{8}$ who examined the effect of EPO on total NO (nitrate and nitrite) in human coronary artery endothelial cells. As in our experiments, these researchers found that a $24 \mathrm{~h}$ incubation with EPO at $5 \mathrm{U} / \mathrm{ml}$ resulted in downregulation of ecNOS protein expression. ${ }^{8}$ Furthermore, EPO significantly reduced $\mathrm{NO}_{x}$ production by both quiescent $(15.4 \pm 1.1 \%)$ and proliferating $(22.2 \pm 1.0 \%)$ endothelial cells. Banerjee et $a l^{31}$ observed that short-term exposure of ECs had little or no effect on NOS transcript. However, in contrast to our results and those of Wang and Vaziri, these researchers detected a significant increase in NOS mRNA after $24 \mathrm{~h}$ of exposure to EPO but cells needed to be exposed to EPO for several days in order to increase NO production. ${ }^{8,31}$

A cross-sectional 3-year prospective placebo-controlled study in a small number of hemodialysis patients revealed that EPO significantly increased plasma MCP-1 concentrations. ${ }^{43}$ After EPO withdrawal MCP-1 concentrations returned to pretreatment levels. Papayianni et $a 1^{44,45}$ compared MCP-1, ICAM-1 and VCAM-1 concentrations in hemodialysis patients. The dialysis session resulted in a significant increase in the plasma concentrations of all three proinflammatory mediators. These observations support the hypothesis that the increased oxidative stress that is known to result from dialysis treatment per se may contribute to the increased expression of proinflammatory mediators. ${ }^{46,47}$

Interestingly, in the study by Papayianni et $a l^{45}$ predialysis concentrations of MCP-1, ICAM-1, and VCAM-1 were also significantly elevated in hemodialysis patients when compared to healthy controls. It is possible that certain disease-associated factors (eg the uremic state per se) may be responsible for the significant difference in predialysis and control MCP-1 concentrations but a contributing effect by EPO cannot be ruled out since more than $86 \%$ of the patients enrolled in this study were treated with EPO. However, since plasma EPO concentrations were not assessed in these two studies and due to other confounders, we cannot conclusively attribute the increased MCP-1 concentrations to EPO therapy.

Nevertheless, these two clinical studies in combination with our in vitro data may provide indirect evidence that EPO may augment endothelial MCP-1 elaboration in vivo which, in turn, may result in the accelerated recruitment of monocytes to atherosclerotic lesions. Probably the most convincing evidence to date for the potential atherogenic effects of EPO is provided by a very intruiging study by Tous et $a l^{48}$ who recently observed that continuous administration of EPO to apolipoprotein E-deficient mice resulted in enhanced lesion size. Unfortunately, the potentially confounding effects of EPO on increased blood pressure are not addressed in this study. Considering the vast number of anemic patients being treated with EPO, our in vitro data in combination with the in vivo observations by Tous et $a l^{48}$ clearly warrant further studies aimed at elucidating the role of EPO in atherogenesis. In the long run, a better understanding of the pro- and antiatherogenic effects of EPO may lead to the development of novel therapeutic agents that correct anemia with maximum vasculoprotective effects.

\section{Acknowledgements}

We are grateful to Robin Kunkel for her excellent technical assistance in preparing the figures in this manuscript. This research was supported by scientist development Grant N004317 from the American Heart Association Midwest Affiliate to Anjali Desai, PhD, MS.

\section{Duality of interest}

The authors have no duality of interest to declare.

\section{References}

1 London GM, Drueke TB. Atherosclerosis and arteriosclerosis in chronic renal failure. Kidney Int 1997;51: 1678-1695.

2 Stenvinkel P, O Heimbürger O Paultre F. Strong association between malnutrition inflammation and atherosclerosis in chronic renal failure. Kidney Int 1999;55:1899-1911.

3 Morris ST, Jardine AG. The vascular endothelium in chronic renal failure. J Nephrol 2000;13:96-105.

4 Adamson JW, Eschbach JW. Erythropoietin for end-stage renal disease. N Engl J Med 1998;339:625.

5 Vaziri ND. Mechanism of Erythropoietin-induced hypertension. Am J Kidney Dis 1999;33:821-827.

6 Haller H, Christel C, Dannenberg L, et al. Signal transduction of erythropoietin in endothelial cells. Kidney Int 1996;50:481-488.

7 Gewaltig MT, Kojda G. Vasoprotection by nitric oxide: mechanisms and therapeutic potential. Cardiovasc Res 2002;55:250-260. 
8 Wang XQ, Vaziri ND. Erythropoietin depresses nitric oxide synthase expression by endothelial cells. Hypertension 1999;33:894-899.

9 Terkeltaub R, Boisvert WA, Curtiss LK. Chemokines and atherosclerosis. Curr Opin Lipidol 1998;19: 387-405.

10 Aiello RJ, Bourassa P-A K, Lindsey SL. Monocyte chemoattractant protein-1 accelerates atherosclerosis in apolipoprotein E-deficient mice. Arterioscler Thromb Vasc Biol 1999;19:1518-1525.

11 Napoli C, Ignarro LJ. Nitric oxide and atherosclerosis. Nitric oxide: Biol Chem 2001;5:88-97.

12 Gauthier TW, Scalia R, Murohara T, et al. Nitric oxide protects against leukocyte-endothelium interactions in the early stages of hypercholesterolemia. Arterioscler Thromb Vasc Biol 1995;15:1652-1659.

13 De Graaf JC, Banga JD, Moncada S, et al. Nitric oxide functions as an inhibitor of platelet adhesion under flow conditions. Circulation 1992;85:2284-2290.

14 Draijer R, Atsma DE, van der Laarse A, et al. CGMP and nitric oxide modulate thrombin-induced endothelial permeability: regulation via different pathways in human aortic and umbilical vein endothelial cells. Circ Res 1995;76:199-208.

15 Cardona-Sanclemente LE, Born GV. Effect of inhibition of nitric oxide synthesis on the uptake of LDL and fibrinogen by arterial walls and other organs of the rat. Br J Pharmacol 1995;114:1490-1494.

16 Rikitake Y, Hirata K, Kawashima S, et al. Inhibitory effect of inducible type nitric oxide synthase on oxidative modification of low density lipoprotein by vascular smooth muscle cells. Atherosclerosis 1998; 136:51-57.

17 Dubey RK, Jackson EK, Luscher TF. Nitric oxide inhibits angiotension II-induced migration of rat smooth muscle cells. Atherosclerosis 1995;136:51-57.

18 Garg YC, Hassid A. Nitric oxide-generating vasodilators and 8-bromocyclic guanosine monophosphate inhibit mitogenesis and proliferation of cultured rat vascular smooth muscle cells. J Clin Invest 1989; 83:1774-1777.

19 Del Castillo D, Raij L, Shultz PJ, et al. The pressor effect of recombinant human erythropoietin is not due to decreased activity of the endogenous nitric oxide system. Nephrol Dial Transplant 1995;10: $505-508$.

20 Tsukahara H, Hiraoka M, Hori C. Chronic erythropoietin treatment enhances endogenous nitric oxide production in rats. Scand J Clin Lab Invest 1997;57: 487-494.

21 Kanagy NL, Perrine MF, Cheung DK, et al. Erythropoietin administration in vivo increases vascular nitric oxide synthase expression. J Cardiovasc Pharmacol 2003;42:4.

$22 \mathrm{Wu}$ XC, Johns EJ, Richards NT. Relationship between erythropoietin and nitric oxide in the contraction of renal arcuate arteries and human umbilical vein endothelial cells. Clin Sci 1999;97:413-419.

23 Vaziri ND, Zhou XJ, Naqvi F. Role of nitric oxide resistance in erythropoietin-induced hypertension in rats with chronic renal failure. Am J Physiol 1996; 271:E113-E122.

24 Schmidt RJ, Baylis C. Total nitric oxide production is low in patients with chronic renal disease. Kidney Int 2000;58:1261-1266.

25 Desai A, Miller MJ, Gomez HF, et al. Loxosceles deserta venom induces NF- $\kappa$ B-dependent chemokine produc- tion by endothelial cells. Clin Toxicol 1999;37: 447-456.

26 Martin TM, Cardarelli PM, Parry GCN, et al. Cytokine induction of monocyte chemoattractant protein-1 gene expression in human endothelial cells depends on the cooperative action of NF- $\kappa \mathrm{B}$ and AP-1. Eur J Immunol 1997;27:1091-1097.

27 Roebuck KA, Carpenter LR, Lakshminarayanan V. Stimulus-specific regulation of chemokine expression involves differential activation of the redox-sensitive transcription factors AP-1 and NF- $\kappa$ B. J Leukoc Biol 1999;65:291-298.

28 Ihling C, Haendeler JG. Co-expression of p53 and MDM2 in human atherosclerosis: implications for the regulation of cellularity of atherosclerotic lesions. J Pathol 1998;185:303-312.

29 Eckart K. After 15 years of success-perspectives of erythropoietin therapy. Nephrol Dial Transplant 2001;16:1745-1749.

30 Buckner FS, Eschbach JW, Haley NR, et al. Hypertension following erythropoietin therapy in anemic hemodialysis patients. Am J Hypertens 1990;3:947-955.

31 Banerjee D, Rodriguez M, Nag M, et al. Exposure of endothelial cells to recombinant human erythropoietin induces nitric oxide synthase activity. Kidney Int 2000;57:1895-1904.

32 Bevilacqua A, Ceriani MC, Capaccioli S, et al. Posttransriptional regulation of gene expression by degradation of messenger RNAs. J Cell Physiol 2003;195: 356-372.

33 Brueckmann M, Marx A, Weiler HM, et al. Stabilization of monocyte chemoattractant protein-1-mRNA by activated protein C. Thromb Haemost 2003;89: 149-160.

34 Vogel Kramer HJ, Backer A. Effects of erythropoietin on endothelin-1 synthesis and the cellular calcium messenger system in vascular endothelial cells. Am J Hypertens 1997;10:289-296.

35 Neusser M, Tepel M, Zidek W. Erythropoietin increases cytosolic free calcium concentration in vascular smooth muscle cells. Cardiovasc Res 1993;27: 1233-1236.

36 Anagnostou A, Lee ES, Kessimian N, et al. Erythropoietin has a mitogenic and positive chemotactic effect on endothelial cells. Proc Natl Acad Sci USA 1990;87:5978-5982.

37 Akimoto T, Kusano E, Muto S. The effect of erythropoietin on interleukin- $1 \beta$ mediated increase in nitric oxide synthesis in vascular smooth muscel cells. J Hypertens 1999;17:1249-1256.

38 Bieber E. Erythropoietin the biology of erythropoiesis and epoetin alfa. An overview. J Reprod Med 2001;46: 521-530.

39 Kusano E, Akimoto $\mathrm{T}$, Inoue $\mathrm{M}$, et al. Human recombinant erythropoietin inhibits interleukin-1bstimulated nitric oxide and cyclic guanosine monophosphate production in cultured rat vascular smooth-muscle cells. Nephrol Dial Transplant 1999; 14:597-603.

40 Nielsen OJ. Pharmacokinetics of recombinant human erythropoietin in chronic haemodialysis patients. Pharmacol Toxicol 1990;66:83-86.

41 Hojs R. Carotid intima-media thickness and plaques in hemodialysis patients. Artif Organs 2000;24:691-695.

42 Vaziri ND, Ni Z, Wang XQ, et al. Downregulation of nitric oxide synthase in chronic renal insufficiency: role of excess PTH. Am J Physiol 1998;274:F642-F649. 
$43 \mathrm{Ni} \mathrm{Z}$, Wang XQ, Vaziri ND. Nitric oxide metabolism in erythropoietin-induced hypertension. Effects of calcium channel blockade. Hypertension 1998;32:724-729.

44 De Marchi S, Cecchin E, Faletti E, et al. Long-term effects of erythropoietin therapy on fistula stenosis and plasma concentrations of PDGF and MCP-1 in hemodialysis patients. J Am Soc Nephrol 1997;8: 1147-1156.

45 Papayianni A, Alexopoulos E, Gaimalis $\mathrm{P}$, et al. Circulating levels of ICAM-1 VCAM-1 and MCP-1 are increased in haemodialysis patients: association with inflammation dyslipidaemia and vascular events. Nephrol Dial Transplant 2002;17:435-441.

46 Morena M, Cristol JP, Canaud B. Why hemodialysis patients are in a prooxidant state? What could be done to correct the pro/antioxidant imbalance. Blood Purification 2000;18:191-199.

47 Nourooz-Zadeh J. Effect of dialysis on oxidative stress in uraemia. Redox Rep 1999;14:17-22.

48 Tous M, Ferre N, Vilella E, et al. Circulating blood cells modulate the atherosclerotic process in apolipoprotein E-deficient mice. Metabolism 2004;53:95-100. 